\title{
Compositional and Geochemical Signatures for the Sedimentary Evolution of the Middle Triassic-Lower Jurassic Continental Redbeds from Western-Central Mediterranean Alpine Chains
}

\author{
Salvatore Critelli, Giovanni Mongelli, ${ }^{1}$ Francesco Perri, ${ }^{1}$ Agustin Martín-Algarra, ${ }^{2}$ \\ Manuel Martín-Martín, ${ }^{3}$ Vincenzo Perrone ${ }^{4}$ Rocco Dominici, \\ Maurizio Sonnino, and Mohamed Najib Zaghloul ${ }^{5}$ \\ Dipartimento di Scienze della Terra, Università degli Studi della Calabria, \\ Via P. Bucci, 87036 Arcavacata di Rende (CS), Italy \\ (e-mail: critelli@unical.it)
}

\begin{abstract}
A B S T R A C T
Compositional and chemical analyses suggest that Middle Triassic-Lower Liassic continental redbeds (in the internal domains of the Betic, Maghrebian, and Apenninic chains) can be considered a regional lithosome marking the TriassicJurassic rift-valley stage of Tethyan rifting, which led to the Pangaea breakup and subsequent development of a mosaic of plates and microplates. Sandstones are quartzose to quartzolithic and represent a provenance of continental block and recycled orogen, made up mainly of Paleozoic metasedimentary rocks similar to those underlying the redbeds. Mudrocks display K enrichments; intense paleoweathering under a hot, episodically humid climate with a prolonged dry season; and sediment recycling. Redbeds experienced temperatures in the range of $100^{\circ}-160^{\circ} \mathrm{C}$ and lithostatic/ tectonic loading of more than $4 \mathrm{~km}$. These redbeds represent an important stratigraphic signature to reconstruct a continental block (Mesomediterranean Microplate) that separated different realms of the western Tethys from MiddleLate Jurassic to Miocene, when it was completely involved in Alpine orogenesis.
\end{abstract}

\section{Introduction and Regional Setting}

Mediterranean orogenic belts preserve key geodynamic signatures from the Pangaea breakup to the Tethys opening and its closure during the growth of Alpine circum-Mediterranean chains. These key paleotectonic phases are marked by clastic sedimentary deposits; their features can be used to reconstruct environmental and sedimentary characteristics of the basins in which they were de2008.

Manuscript received October 26, 2007; accepted March 17,

${ }^{1}$ Dipartimento di Scienze Geologiche, Università degli Studi della Basilicata, Campus di Macchia Romana, 85100 Potenza, Italy.

${ }^{2}$ Departamento de Estratigrafía y Paleontología de la Universidad de Granada, Campus de Fuentenueva, 18071 Granada, Spain.

${ }^{3}$ Departamento de Ciencias de la Tierra y del Medio Ambiente de la Universidad de Alicante, Campus de San Vicente, Apdo. Correos 99, 03080 Alicante, Spain.

${ }^{4}$ Istituto di Scienze della Terra, Università "Carlo Bo" di Urbino, Località Crocicchia, 61029 Urbino, Italy.

${ }^{5}$ Département de Sciences de la Terre de 1'Université "Abdel Maleek Essâadi" de Tanger, Tangier, Morocco. posited and to test alternative paleogeographic and paleotectonic reconstructions (e.g., Critelli 1999).

In many internal units of the Betic (Spain), Rif (Morocco), Tell (Algeria), and Apenninic chains (Italy; fig. 1), the onset of Mesozoic-to-Cenozoic sedimentation was marked by deposition of continental clastics (redbeds), known as Verrucanotype deposits. Perrone et al. (2006) recognized two redbed subdomains, the Pseudoverrucano Subdomain and the Verrucano Subdomain, characterized by different sedimentary successions in Pangaea during Middle Triassic-Early Liassic time (fig. $2 A$, $2 B)$. The aim of this article is to detail petrographic and geochemical features of the Pseudoverrucano Subdomain redbeds characterizing (1) the Pseudoverrucano unit in the Northern Apennines; (2) the Sila, Stilo, Piraino, and Longi-Taormina units in the Calabria-Peloritani Arc; (3) the "Chaîne Calcaire" units in the Tell Chain; (4) the Ghomaride and Internal "Dorsale" Calcaire units in the Rif Chain; and (5) the Malaguide units in the Betic Cordillera. 


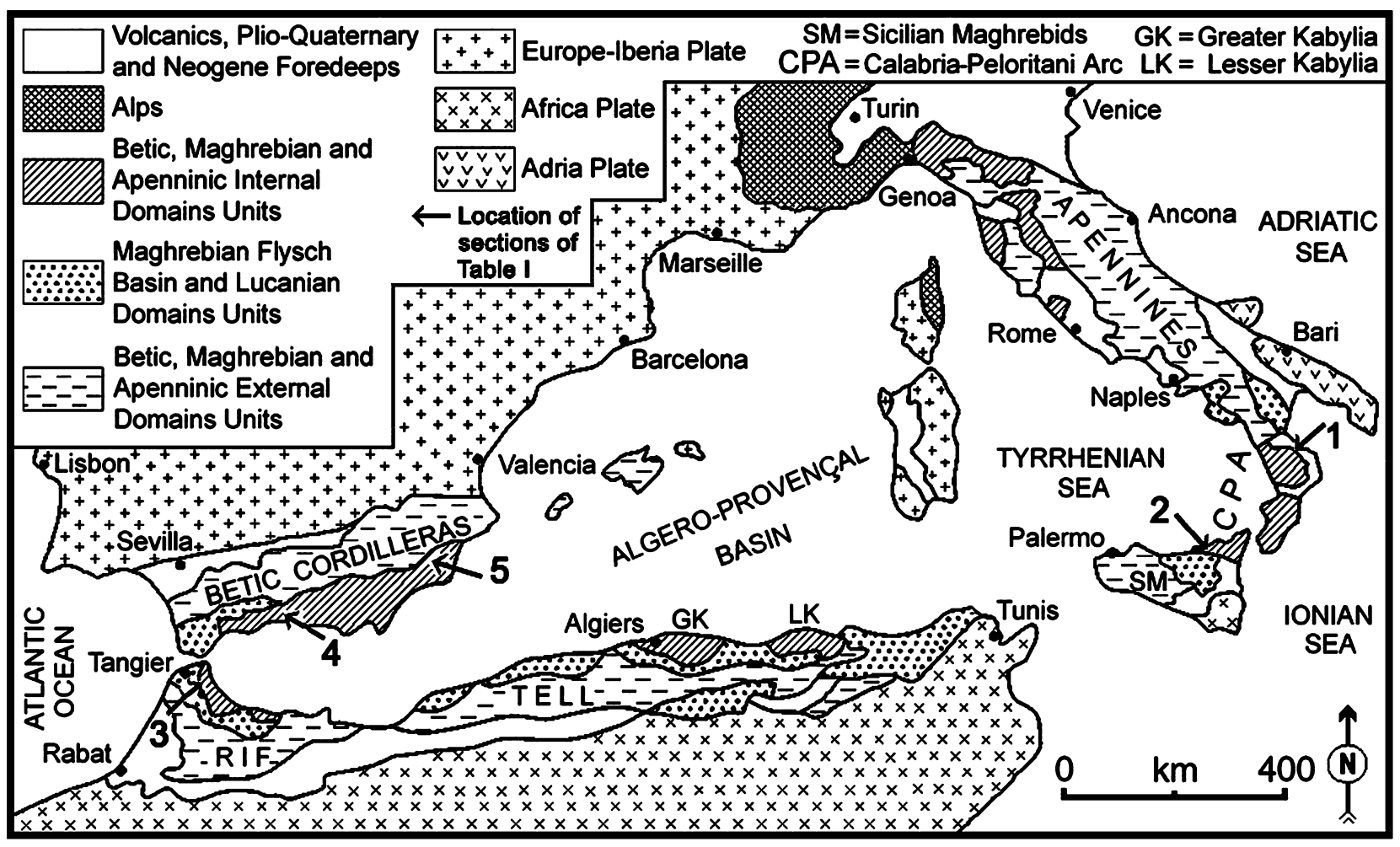

Figure 1. Geological sketch map of the Alpine Chains in the Central-Western Mediterranean region (after Perrone et al. 2006) and location of the sections of table 1. Maghrebian Chain includes the Rif Chain in Morocco, the Tell Chain in Algeria, and the Sicilian Maghrebian in Sicily.

We report data only for the Pseudoverrucano Subdomain because this succession everywhere is preserved as sedimentary rocks, in contrast to the Verrucano Subdomain, where succession is affected by intense metamorphic processes.

The oldest redbeds are Anisian (fig. 3, $T_{2}$ ) in age, and in some regions, they reach earliest Jurassic (Perrone et al. 2006 and references therein). In a few localities in the Pseudoverrucano Subdomain, thin layers of Ladinian (fig. 3, $T_{3}$ ) dolostones and limestones and Carnian (fig. 3, $T_{4}$ ) evaporites are interbedded within alluvial facies, which persist up to Rhaetian (fig. 3, $T_{6}$ ) or Hettangian (fig. $3, J_{1}$ ), where they pass to carbonate platform strata. Only in the eastern Betics do Ladinian-Carnian $\left(T_{3}-T_{4}\right)$ carbonates reach remarkable thickness.

In the Verrucano Subdomain (stratigraphic succession is not included in fig. 3 because of its metamorphic overprint), in contrast, AnisianLadinian $\left(T_{2}-T_{3}\right)$ thick marine sediments and two sedimentary cycles locally bounded by a disconformity are recognizable. The upper cycle also starts with alluvial and/or coastal deposits, which pass to Carnian $\left(T_{4}\right)$ evaporites, overlain by Norian $\left(T_{5}\right)$ platform carbonates. As from the Middle
Liassic, both the Verrucano and the Pseudoverrucano subdomains are characterized by similar successions, mainly represented by pelagic sediments. During the late Oligocene-early Miocene, compressional tectonics affected the two subdomains in quite different ways: the Verrucano Subdomain was affected by polyphase metamorphism, indicating subduction to depths up to $40 \mathrm{~km}$, and later by rapid exhumation, whereas the Pseudoverrucano Subdomain originated the highest units of the nappe stack, which generally were not metamorphosed (Perrone et al. 2006 and references therein).

The main features of the significant Pseudoverrucano stratigraphic successions (fig. 3) are as follows. (1) Redbeds lie on pre-Alpine basement, in which the youngest terranes are lower Upper Carboniferous clastics or late-Variscan plutonites. (2) Redbed successions are lithologically homogeneous. Their stratigraphy has been described in detail for the Malaguide-Ghomaride Saladilla Formation (Martín-Algarra et al. 1995). Redbeds are reddish or purple, rarely greenish or yellowish. Quartzose conglomerates and coarse sandstones dominate in the lower portions, whereas fine sandstones and mudrocks prevail in the upper 

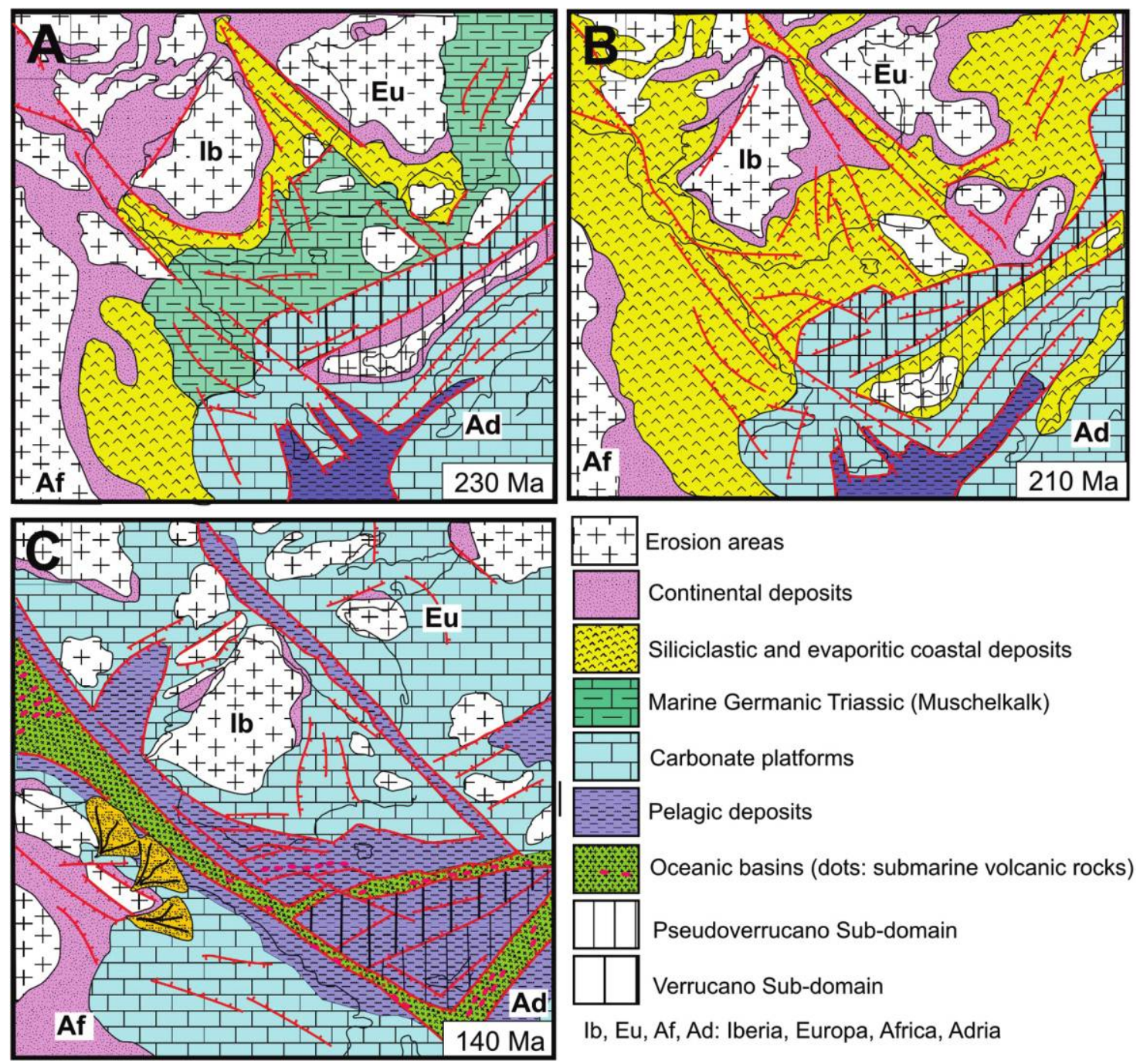

Figure 2. Ladinian $(A)$, Norian $(B)$, and Earliest Cretaceous $(C)$ paleogeographic sketch maps of the westernmost Tethys area (modified and redrawn after Vera 2004). The space of vertical lines showing the Verrucano Subdomain is about twice that of the Pseudoverrucano Subdomain.

portions. Thickness ranges from a few to more than $400 \mathrm{~m}$. The sedimentary facies associations suggest alluvial-fan, braided- and alluvial-plain fluvial environments. (3) Redbeds are overlain by HettangianSinemurian (fig. 3, $J_{1}-T_{2}$ ) platform carbonates, commonly with Rhaetian (fig. 3, $T_{6}$ ) to Hettangian (fig. 3, $\left.J_{1}\right)$ clastic and dolomitic transitional deposits. (4) Above the Pliensbachian (fig. $3, J_{3}$ ), successions are generally pelagic. The uppermost beds are Chattian-Aquitanian (fig. 3, $\mathrm{O}_{2}-M_{1}$ ) turbidites.

\section{Composition and Provenance}

Compositional data from 57 sandstones from 15 representative stratigraphic sections of Pseudoverrucano redbeds are here discussed for provenance relations of these clastic sediments. Sandstones are analyzed using the Gazzi-Dickinson method (e.g., Ingersoll et al. 1984; Zuffa 1985), and recalculated parameters used in diagrams are those of Ingersoll and Suczek (1979) and Dickinson (1985). Sandstones are quartzarenite to quartzolithic (fig. 4). They are characterized by abundant monocrystalline and polycrystalline quartz, whereas feldspars are minor or absent. Lithic fragments include metasedimentary rocks (phyllite, metarenite, quartzite, slate, metalimestone, and metachert) and minor felsitic volcanic grains. Mafic volcanic fragments are absent or rare. The limited importance of a mafic supply for these successions is confirmed by geochemical provenance proxies: in the La-ThSc plot (fig. $5 a$ ), the redbed mudrocks fall in a region 

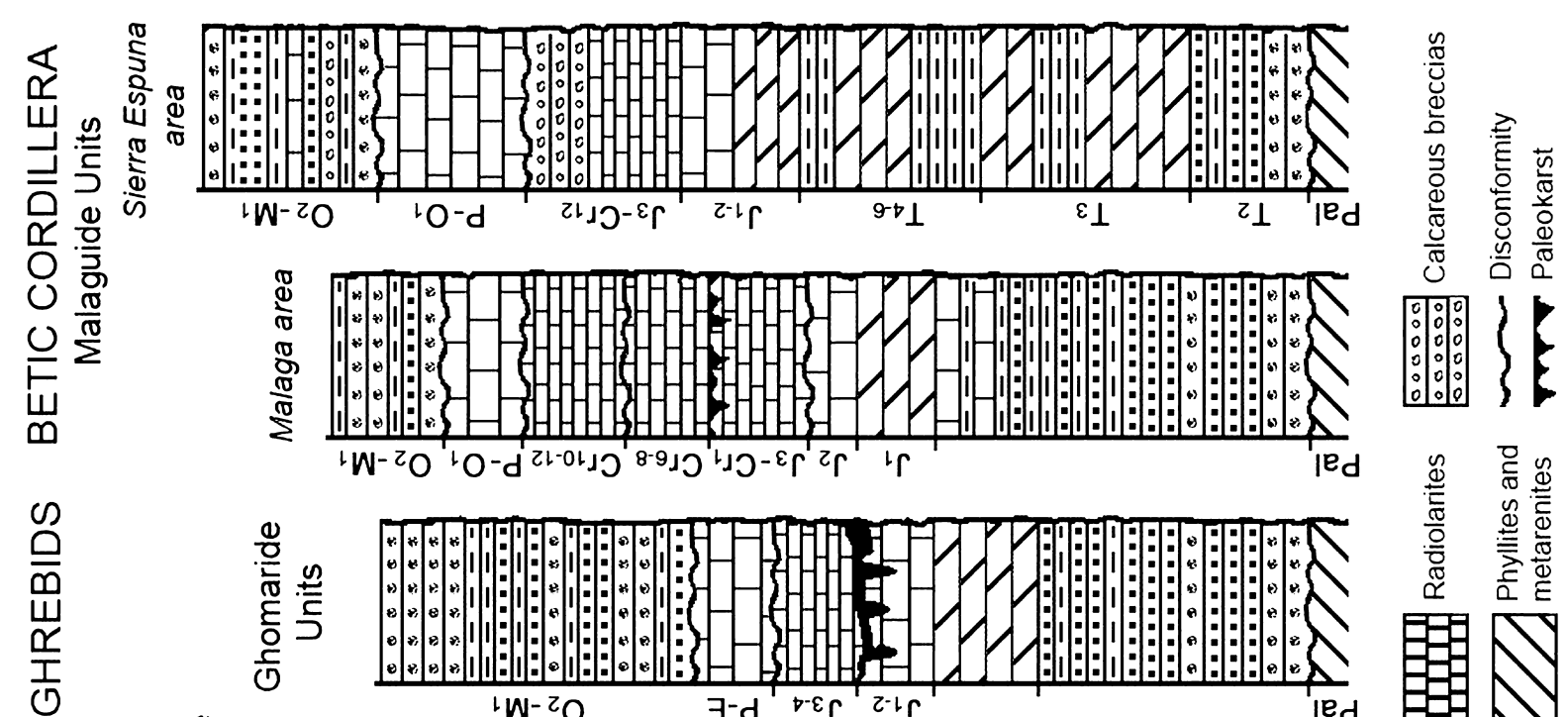

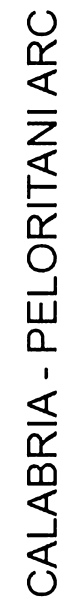
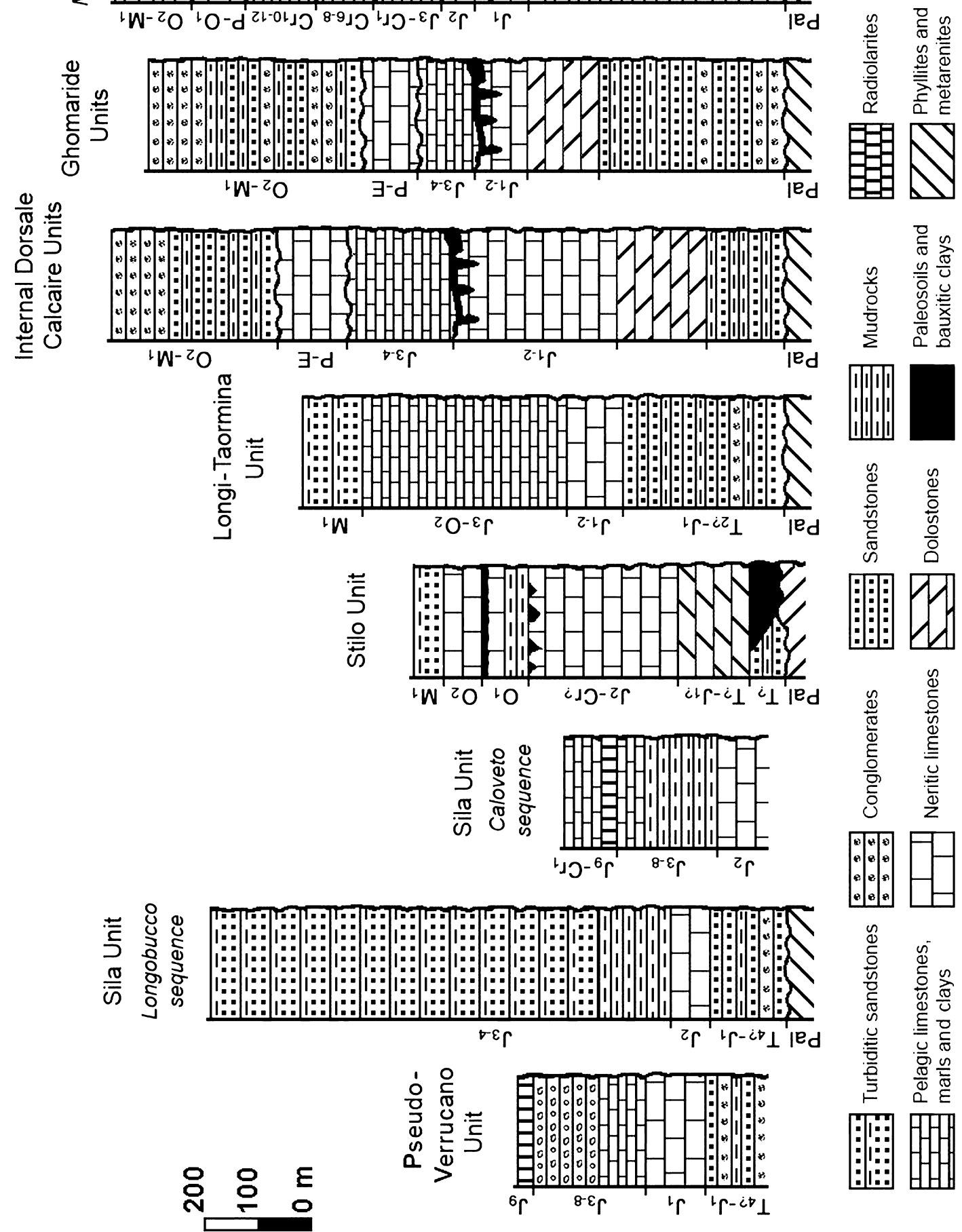

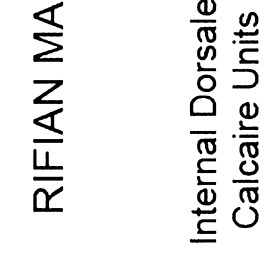

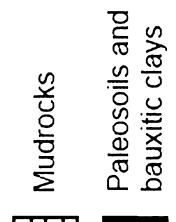

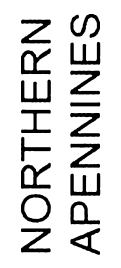
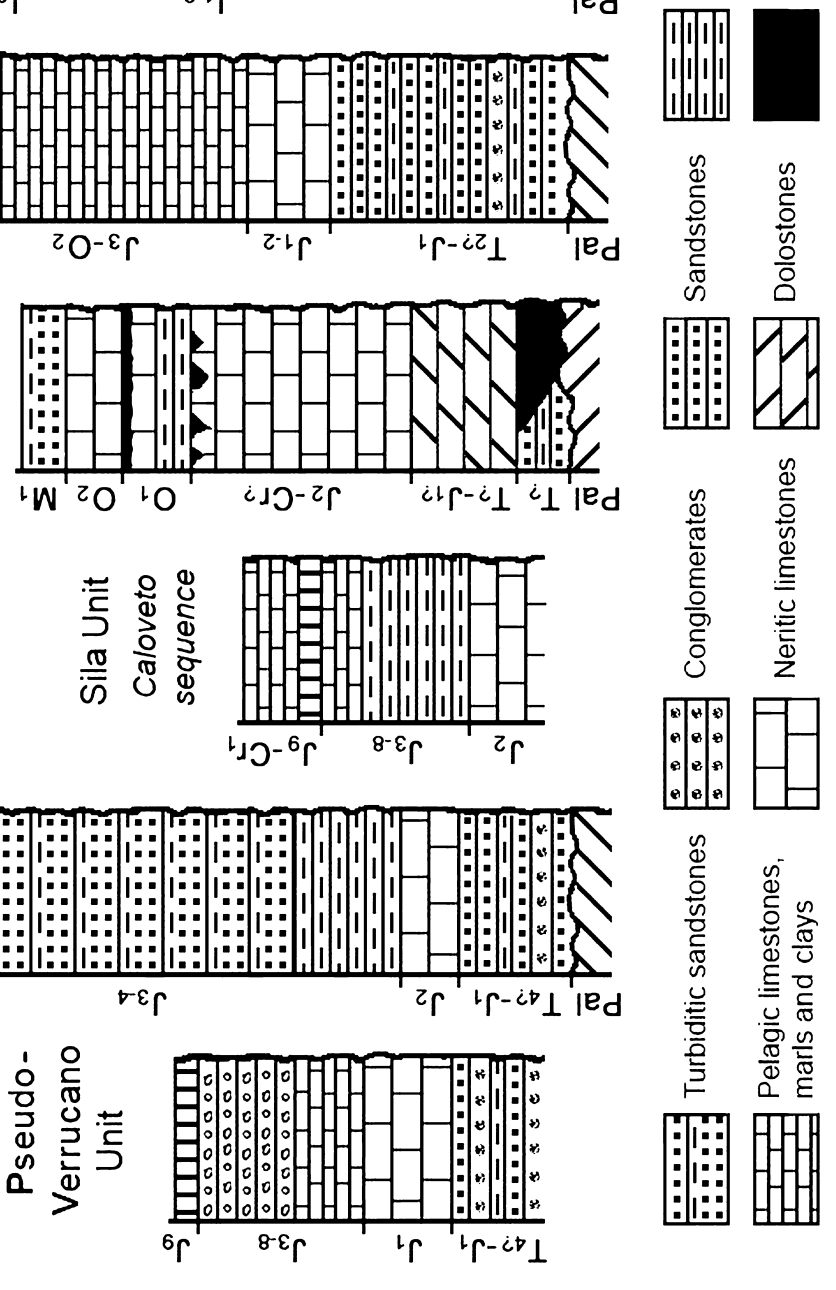
close to the Post-Archean Australian Shale (PAAS; Taylor and McLennan 1985) point, clearly ruling out a predominantly mafic source (Bhatia and Crook 1986; Cullers 1994). A significant maficultramafic supply is also excluded on the basis of the mixing curve between granite and a maficultramafic end member in the $\mathrm{Y} / \mathrm{Ni}$ versus $\mathrm{Cr} / \mathrm{V}$ diagram (fig. $5 b$ ).

Conglomerate clasts are mainly quartzite but include the same rock types as the lithic fragments in sandstone. In all regions, sandstone suites plot within the provenance fields for both continental blocks and recycled orogens (e.g., Dickinson 1985; fig. 4).

The nature of both coarse and fine clastics suggests a provenance of dominantly Cambrian to Carboniferous clastic, carbonate, and cherty metasedimentary successions, similar to those underlying the redbeds and referable to Variscan and preVariscan orogenies. In the Calabria-Peloritani Arc, these successions include mafic and felsic Paleozoic metavolcanics (Spalletta and Vai 1989; Trombetta et al. 2004) and are intruded by late-Variscan large plutonic bodies and rare Upper CarboniferousPermian small rhyolite and felsic dykes.

These plutonic rocks contributed only minor clastic material to the redbeds. Plutonic rock fragments are rare or absent in both sandstone and conglomerate, and the only possible signal of these source rocks is the minor presence of $\mathrm{K}$-feldspar and plagioclase. Possible explanations for the absence of derivation from Upper Paleozoic plutonic rocks are that (1) these plutonic bodies were scarcely exposed or (2) chemical weathering and cumulative effects of sedimentary recycling mask the source rock signal. The chemical weathering and sedimentary recycling of such rocks under a hot, episodically humid climate with a prolonged dry season would produce illitization of silicate minerals, oxidation of iron, and concentration of quartz in thick soil profiles that were later denuded by fluvial erosion, producing relatively mature quartz-rich red deposits (e.g., Suttner et al. 1981; Basu 1985).
The mudrocks in the redbed successions, analyzed in detail along five sections, are composed mainly of clay minerals (illite, illite-smectite [I-S] mixed layers, kaolinite, and chlorite), quartz, hematite or goethite (only for the samples of the Bocchigliero section), and negligible feldspars. In some Betic samples, discrete amounts of calcite and/or dolomite are present (fig. 6). The $<2-\mu \mathrm{m}$ grain size fraction is composed by illite prevailing over I-S mixed layers, kaolinite, and negligible amounts of chlorite, as suggested by x-ray diffractogram patterns.

The mudrock samples show a content of illitic layers in the I-S mixed layers in a range of $70 \%-90 \%$ (Reickeweite number, $R$ ordering $=1-3$; Jadgozinski 1949). The illite crystallinity (IC) value, measured on both air-dried and ethylene-glycol-solvated oriented mounts, are in a range of $0.6^{\circ}-0.7^{\circ} \Delta 2 \theta$ $\mathrm{CuK} \alpha$ (fig. 7; table 1). The IC values, coupled with high ordering of mixed layers and high content of illitic layers in I-S mixed layers, suggest that the redbeds experienced temperatures in the range of $100^{\circ}-160^{\circ} \mathrm{C}$, testifying to intense diagenetic conditions (upper limit of late diagenesis; Jaboyedoff and Théllin 1996; Frey and Robinson 1999).

Diagenetic effects on Pseudoverrucano sandstones include mechanical compaction with consequent deformation of mica flakes and the crystal morphology of aggregate kaolinite-dickite booklets that document the late/deep diagenetic stage for the studied successions. These mineralogical and petrographical considerations suggest that diagenetic/ tectonic evolution of the analyzed redbeds should correspond to a lithostatic/tectonic loading of more than $4 \mathrm{~km}$.

\section{Paleoweathering, Sorting, and Recycling Processes}

Chemical data from redbed mudrocks provide information about source area composition, paleoweathering, sorting, and recycling. Weathering processes in source areas have been characterized

Figure 3. Stratigraphic columns of Northern Apennines, Calabria-Peloritani Arc, Rifian Maghrebdis (Rif Chain), and Betic units showing significative Middle Triassic-Lower Liassic redbed successions. Ages: Pal= Paleozoic, $T_{?}=$ Triassic?, $T_{?}-J_{1}$ ? $=$ Triassic?-Hettangian?, $T_{2}=$ Anisian, $T_{2}$ ?- $J_{1}=$ Anisian?-Hettangian, $T_{3}=$ Ladinian,$~ T_{4}=$ Carnian, $T_{4-6}=$ Carnian-Rhaetian, $T_{4}$ - $J_{1}=$ Carnian?-Hettangian, $J_{1}=$ Hettangian, $J_{1-2}=$ Hettangian-Sinemurian, $J_{2}=$ Sinemurian, $I_{2}-C r_{?}=$ Sinemurian-Cretaceous?, $J_{3-4}=$ Pliensbachian-Toarcian, $J_{3-8}=$ Pliensbachian-Callovian, $J_{3}-C_{1}=$ Pliensbachian-Berriasian, $\quad J_{3}-C_{12}=$ Pliensbachian-Maastrichtian, $J_{3}-O_{2}=$ Pliensbachian-Chattian, $J_{9}=$ Oxfordian, $\quad J_{9}-C_{1}=$ Oxfordian-Berriasian, $\quad C r_{6-8}=$ Albian-Turonian, $\quad C r_{10-12}=$ Santonian-Maastrichtian, $\quad P-E=$ Paleocene-Eocene, $P-O_{1}=$ Paleocene-Rupelian, $O_{1}=$ Rupelian, $O_{2}=$ Chattian, $O_{2}-M_{1}=$ Chattian-Aquitanian, $M_{1}=$ Aquitanian. 


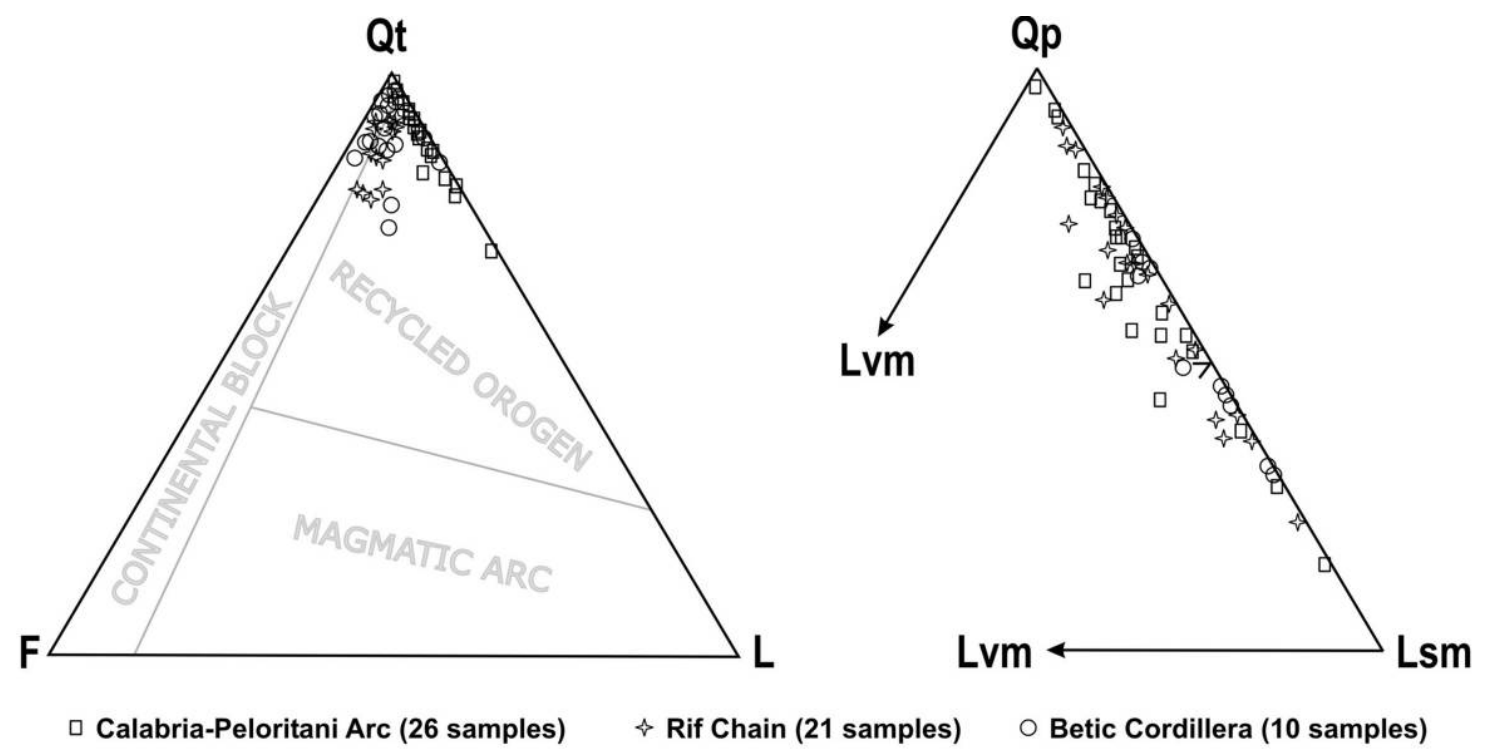

Figure 4. Total quartz-feldspar-lithic fragment (Qt-F-L) and polycrystalline quartz-volcanic and metavolcanic lithic fragment-sedimentary and metasedimentary lithic fragment (Qp-Lvm-Lsm) ternary plots (Ingersoll and Suczek 1979; Dickinson 1985) of the sandstone samples.

using the chemical index of alteration $(\mathrm{CIA}$; Nesbitt and Young 1982), the chemical index of weathering (CIW; Harnois 1988), and the plagioclase index of alteration (PIA; Fedo et al. 1995). The CIA values for all redbed samples are low (table 1), and they plot along the A-K side of the A-CN-K diagram, close to the muscovite-illite fields (fig. 8); this suggests $\mathrm{K}$ enrichment during burial, as testified by mineralogical data.

Generally, K enrichment may have been related to the partial conversion of 1:1 clay minerals into $2: 1 \mathrm{~K}$-rich clay minerals or the presence of postdepositional K-rich fluids. In these cases, K enrichment in the system was responsible for the abrupt reduction of CIA values. In these cases, the CIA proxy should be used with care (Nesbitt and Young 1989; Fedo et al. 1995).

In our case, some samples are typically high in $\mathrm{K}_{2} \mathrm{O}$ and low in $\mathrm{Na}_{2} \mathrm{O}$ because of alkali exchange (e.g., Lipman 1964); this behavior, reflecting a reasonable potassium metasomatism (e.g., Ratté and Steven 1967; Sweetkind et al. 1993), may be related to preweathering $\mathrm{K}$ enrichment within source terranes (e.g., Fedo et al. 1995). As a consequence, the CIA should correctly detect the degree of weathering in source areas.

The redbeds have uniform CIW values (table 1), close to the A apex in the A-C-N plot (fig. 9); this suggests intense weathering under steady state conditions, where the material removal rate matched the production of mineralogically uniform weath- ering profiles generated in the upper zone of soil horizons. Unweathered plagioclase has a PIA value of 50, whereas the PAAS has a PIA value of 79 . The redbeds have very high PIA values (table 1), suggesting that most of the plagioclase has been converted to clay minerals. Thus, results from both the CIW and the PIA indicate intense weathering in source areas.

Although rare earth elements are quantitatively transferred from sources to sediment, intense weathering produces light rare earth element/heavy rare earth element fractionation, possibly due to preferential heavy rare earth element retention in the solution, which, in mudrocks, may be recognized by both higher values of the $(\mathrm{La} / \mathrm{Yb})_{\mathrm{ch}}$ ratio relative to the $(\mathrm{La} / \mathrm{Yb})_{\mathrm{ch}}$ of the PAAS and the Upper Continental Crust (UCC; Taylor and McLennan 1985) and significant correlation between this ratio and weathering indices (Mongelli 2004; Mongelli et al. 2006). In the present case, the $(\mathrm{La} / \mathrm{Yb})_{\text {ch }}$ ratio is lower than the $(\mathrm{La} / \mathrm{Yb})_{\mathrm{ch}}$ ratio of the PAAS, and it is not correlated with the weathering indices. Furthermore, the redbed samples are characterized by sedimentary recycling, as indicated in $\mathrm{Al}_{2} \mathrm{O}_{3}-\mathrm{TiO}_{2}$ $\mathrm{Zr}$ and $\mathrm{Zr} / \mathrm{Sc}$ versus Th/Sc diagrams (Garcia et al. 1991). A mixing trend, characterized mostly by changes in the $\mathrm{Al}_{2} \mathrm{O}_{3}-\mathrm{TiO}_{2}-\mathrm{Zr}$ ratio, which could be due to a recycling effect, is clearly envisaged in the ternary $\mathrm{Al}_{2} \mathrm{O}_{3}-\mathrm{TiO}_{2}-\mathrm{Zr}$ diagram (fig. 10a). In the $\mathrm{Zr} / \mathrm{Sc}$ versus $\mathrm{Th} / \mathrm{Sc}$ diagram (fig. 10b), the redbeds are not clustered along the primary compositional 
a)

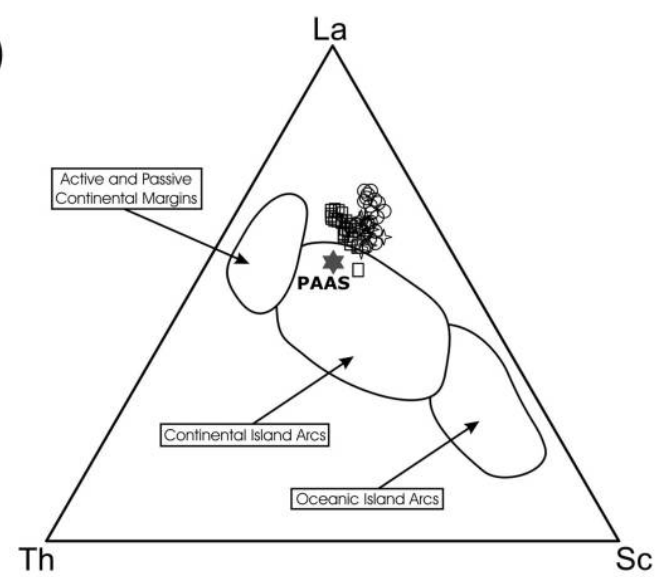

b)

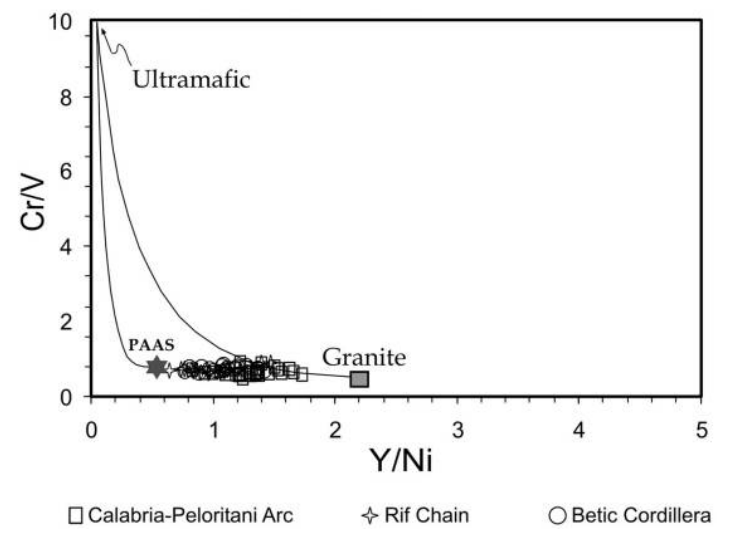

Figure 5. La-Th-Sc plot $(a)$ and $\mathrm{Cr} / \mathrm{V}$ versus $\mathrm{Y} / \mathrm{Ni}$ diagram $(b)$ of mudrock samples. Ultramafic sources have very low $\mathrm{Y} / \mathrm{Ni}$ and high $\mathrm{Cr} / \mathrm{V}$ ratios. The samples fall in a region close to the Post-Archean Australian Shale point, ruling out mafic supply.

trend but fall along a trend involving zircon addition and thus sediment recycling, consistent with the $\mathrm{Al}_{2} \mathrm{O}_{3}-\mathrm{TiO}_{2}-\mathrm{Zr}$ diagram. Sediment recycling significantly affects the CIW and PIA weathering indices, which likely monitor a cumulative effect, including several cycles of weathering at the source.

\section{Conclusions}

The studied Middle Triassic-Lowermost Jurassic continental redbeds are preserved in rifted-margin prisms of many tectonic units from the internal domains of the Apenninic, Maghrebian, and Betic chains. They have paleogeographical significance at the scale of the Central-Western Mediterranean Chain.

Redbeds are characterized by fluviatile quartzarenitic-quartzolithic sandstones, derived from a continental block-recycled orogen, consisting of
Variscan or older metasedimentary and plutonic rocks. Their mudrocks are chemically and mineralogically almost homogeneous, and no important differences in oxide ratios or key trace element ratios have been found. The mineralogical assemblage, dominated by illite and I-S mixed layers, coupled with the CIA index and to the A-CN-K plot, indicates $\mathrm{K}$ enrichment during sedimentary evolution, which may be related to $\mathrm{K}$ enrichment within source terranes, with the $\mathrm{K}^{+}$cation going into solution after weathering of $\mathrm{K}$-feldspar in clay minerals.

Recycling effects from the metasedimentary basement rocks, which influenced the paleoweathering indices (CIW and PIA ratios), are characterized by the distribution of $\mathrm{Al}_{2} \mathrm{O}_{3}, \mathrm{TiO}_{2}$, and $\mathrm{Zr}$, which, together with the $\mathrm{Zr} / \mathrm{Sc}$ versus $\mathrm{Th} / \mathrm{Sc}$ plot, involve zircon addition and thus sediment recycling. The weathering indices probably monitor cumulative recycling effects, including a first cycle of the weathering of source rocks. The Middle Triassic-Early Jurassic time span was characterized by seasonal climate alternation that favored recycling processes (Perrone et al. 2006 and references therein).

The clay-mineral features and mineralogy of authigenic interstitial components suggest that the redbeds experienced temperatures in the range of $100^{\circ}-160^{\circ} \mathrm{C}$ and, based on a geothermal gradient of about $25^{\circ}-30^{\circ} \mathrm{C} / \mathrm{km}$ (Mongelli et al. 1996), a lithostatic/tectonic loading of more than $4 \mathrm{~km}$ (Mongelli et al. 2006; Perri 2008).

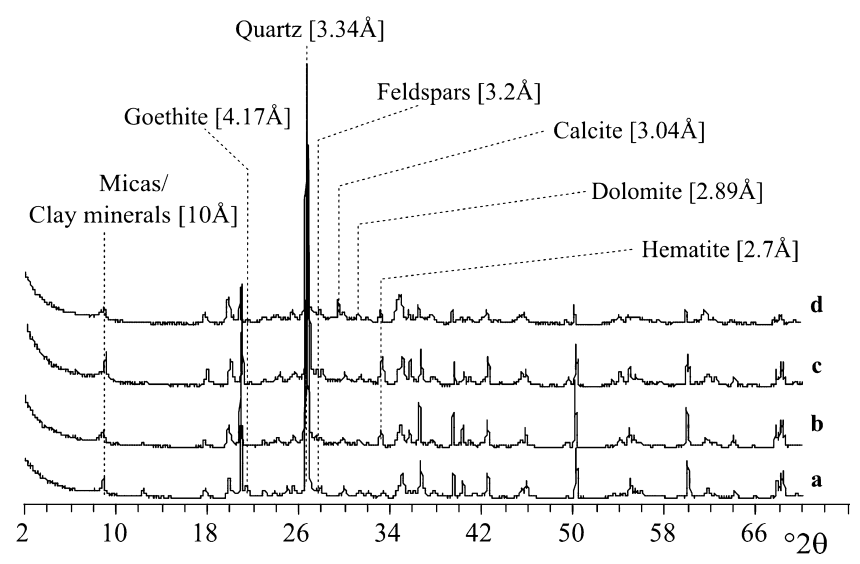

Figure 6. The x-ray diffractogram patterns of some whole-rock samples: Calabria-Peloritani Arc la; Sila Unit, Bocchigliero section), Calabria-Peloritani Arc (b; Longi-Taormina Unit, Longi section), Rifian Maghrebids $(c$; Ghomaride Koudiat Tiziane Nappe, Aïn el Jir section), and Betic Cordillera (d; Malaguide Complex, Arroyo Zapateros section). 


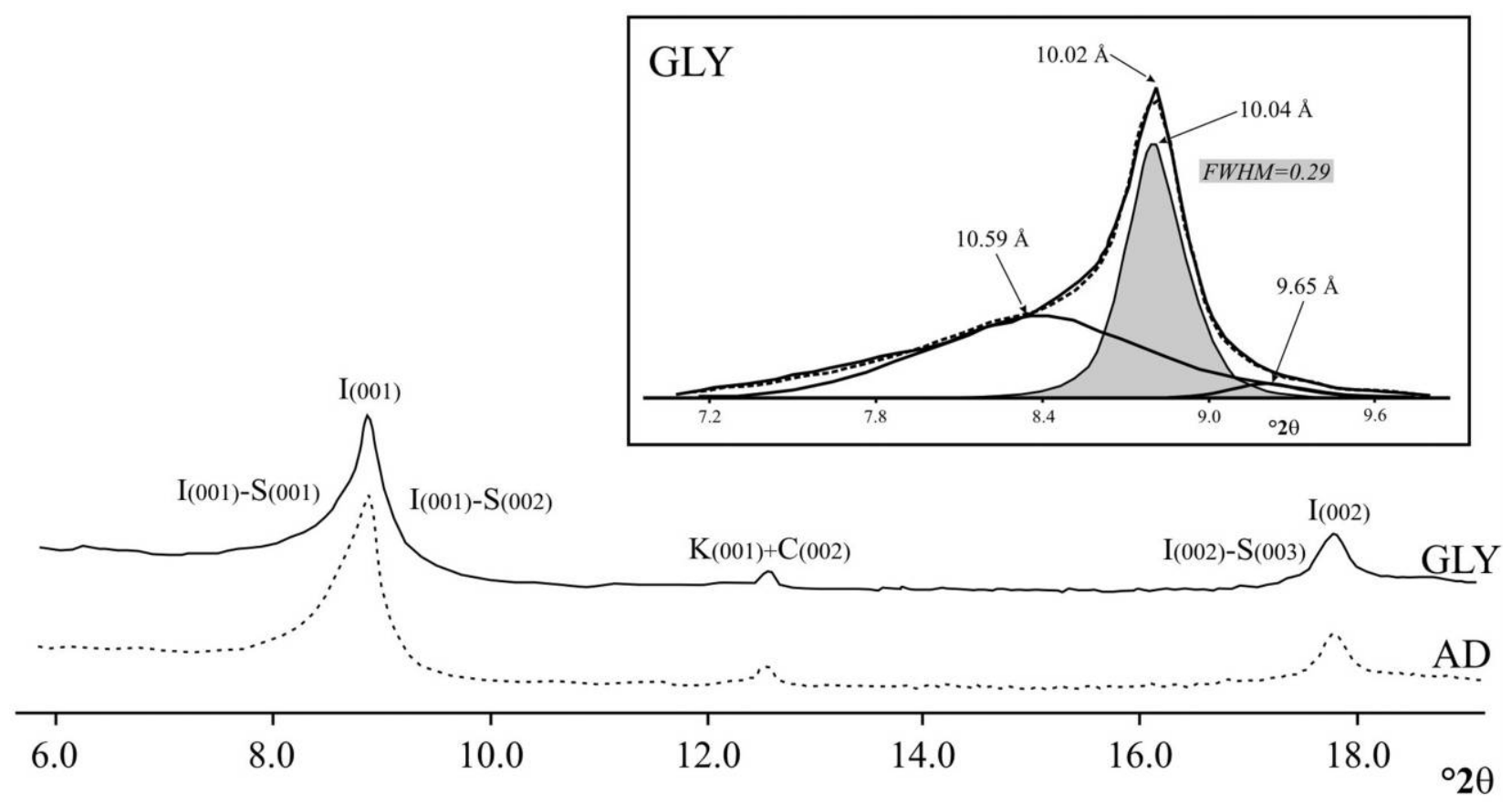

Figure 7. Example of decomposition of x-ray diffractogram pattern of the illitic phases in the mudrock sample FP36 (Rifian Maghrebids; Koudiat Tiziane Nappe). In this study, the full width at half-maximum ( $y$ ) was transformed into crystallinity index standard data $(x)$ according to the equation $y=2.2366 x+0.0243\left(R^{2}=0.98\right)$, obtained in the laboratory using the international standards of Warr and Rice (1994). GLY= glycolated pattern; $A D=$ air-dried.

The continental redbeds represent the oldest strata of successions with a similar tectonosedimentary evolution from the Middle Triassic to compressional deformation, and they represent the onset of Mesozoic sedimentation during the rift-valley stage of the Pangaea breakup. The continental redbeds pass upward to transitional shallow-marine and deep-marine mainly carbonate sequences that represent the following protooceanic stage and precede the opening of the western Tethys (Perrone et al. 2006 and references therein; fig. $2 A, 2 B)$. The close similarity in composition, sedimentology, and diagenetic evolution of the redbeds in different sectors of the circum-
Mediterranean orogens suggests deposition in a distinctive Mesozoic belt (Pseudoverrucano Subdomain; Perrone et al. 2006).

The redbeds were deposited on a block of Variscan continental crust. This block had a central erosional mountain area that provided terrigenous sediments to surrounding intracontinental rift basins. After having been deeply eroded during the Triassic, the mountain areas were transformed to a peneplaned area of low relief, whereas the former continental basins evolved to neritic carbonate basins after the start of the Early Jurassic.

The continental Pseudoverrucano basin passed laterally to areas characterized as Ladinian by an

Table 1. Analytical Data of Mudrocks Sampled in Selected Sections

\begin{tabular}{lccccc}
\hline Section & Bocchigliero & Longi & Aïn el Jir & Arroyo Zapateros & Sierra Espuña \\
\hline Location in figure & 1 & 2 & 3 & 4 & 5 \\
IC $\left(\Delta^{\circ} 2 \theta\right)$ & $>.65,<.72$ & $>.62,<.70$ & $>.67,<.73$ & $>.69,<.74$ & $>.70,<.77$ \\
\%I in I-S & $>75,<90$ & $>75,<90$ & $>75,<85$ & $>70,<85$ & $>70,<85$ \\
CIA & $70 \pm 1.8$ & $72 \pm 3.1$ & $72 \pm 4.1$ & $68 \pm 2.0$ & $74 \pm 1.2$ \\
CIW & $97 \pm .7$ & $96 \pm 1.3$ & $94 \pm 2.9$ & $94 \pm 3.3$ & $94 \pm 1.1$ \\
PIA & $95 \pm 1.1$ & $94 \pm 1.7$ & $92 \pm 3.7$ & $91 \pm 3.9$ & $92 \pm 1.5$ \\
\hline
\end{tabular}

Note. Sections: Calabria-Peloritani Arc: 1, Sila Unit, Bocchigliero section; 2, Longi-Taormina Unit, Longi section. Rifian Maghrebids: 3, Ghomaride Koudiat-Tiziane Nappe, Aïn el Jir section. Betic Cordillera: 4, Malaguide Complex, Arroyo Zapateros section; 5, Malaguide Morron de Totana Unit, Sierra Espuña section. IC = illite crystallinity values; \%I in I-S = percentage of illite layers in the illite-smectite mixed layers; CIA = chemical index of alteration (Nesbitt and Young 1982); CIW = chemical index of weathering (Harnois 1988); PIA = plagioclase index of alteration (Fedo et al. 1995). 


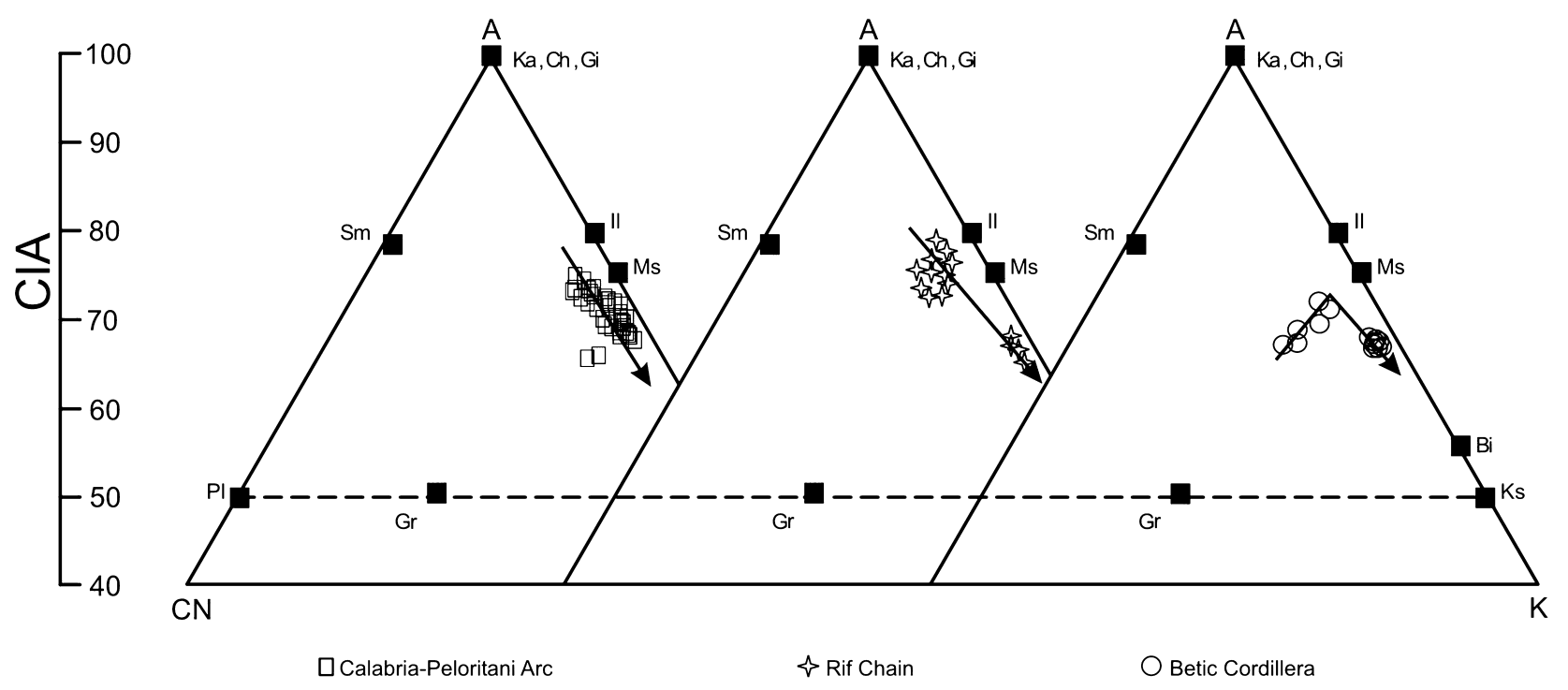

Figure 8. Ternary A-CN-K plots of the mudrock redbeds. $G r=$ granite, $M s=$ muscovite, $I l=$ illite, $K a=$ kaolinite, $C h=$ chlorite, $G i=$ gibbsite, $S m=$ smectite, $\mathrm{Bi}=$ biotite, $\mathrm{Ks}=\mathrm{K}$-feldspar, $\mathrm{Pl}=$ plagioclase, $A=\mathrm{Al}_{2} \mathrm{O}_{3}, C N=\mathrm{CaO}+$ $\mathrm{Na}_{2} \mathrm{O}, K=\mathrm{K}_{2} \mathrm{O}, C I A=$ chemical index of alteration (Nesbitt and Young 1982). The samples fall close to the A-K join along a trend indicating $\mathrm{K}$ addition during diagenesis.

earlier tectonosedimentary evolution, testified by shallow-marine carbonates interbedded with fluvial deposits, an intra-Ladinian disconformity, Carnian evaporites, and generalized carbonate platform environments in the Norian-Rhaetian (Verrucano Subdomain; Perrone et al. 2006; fig. 2A, 2B). Only in the Sinemurian do similar carbonate neritic sediments characterize both subdomains, which in the Pliensbachian generally evolved to hemipelagic deposits. A common sedimentary history, pointed out by the persistence of pelagic facies, is recognizable up to the onset of convergence-related tectonics, when the two subdomains experienced quite different evolution.

The Triassic Pseudoverrucano-Verrucano Domains were surrounded by the Germano-Andalusian facies, now cropping out in the Iberian and African plates, whereas eastward it opened toward Tethyan marine domains (fig. 2A, 2B). Moreover, the Pseudoverrucano-Verrucano Domains had a

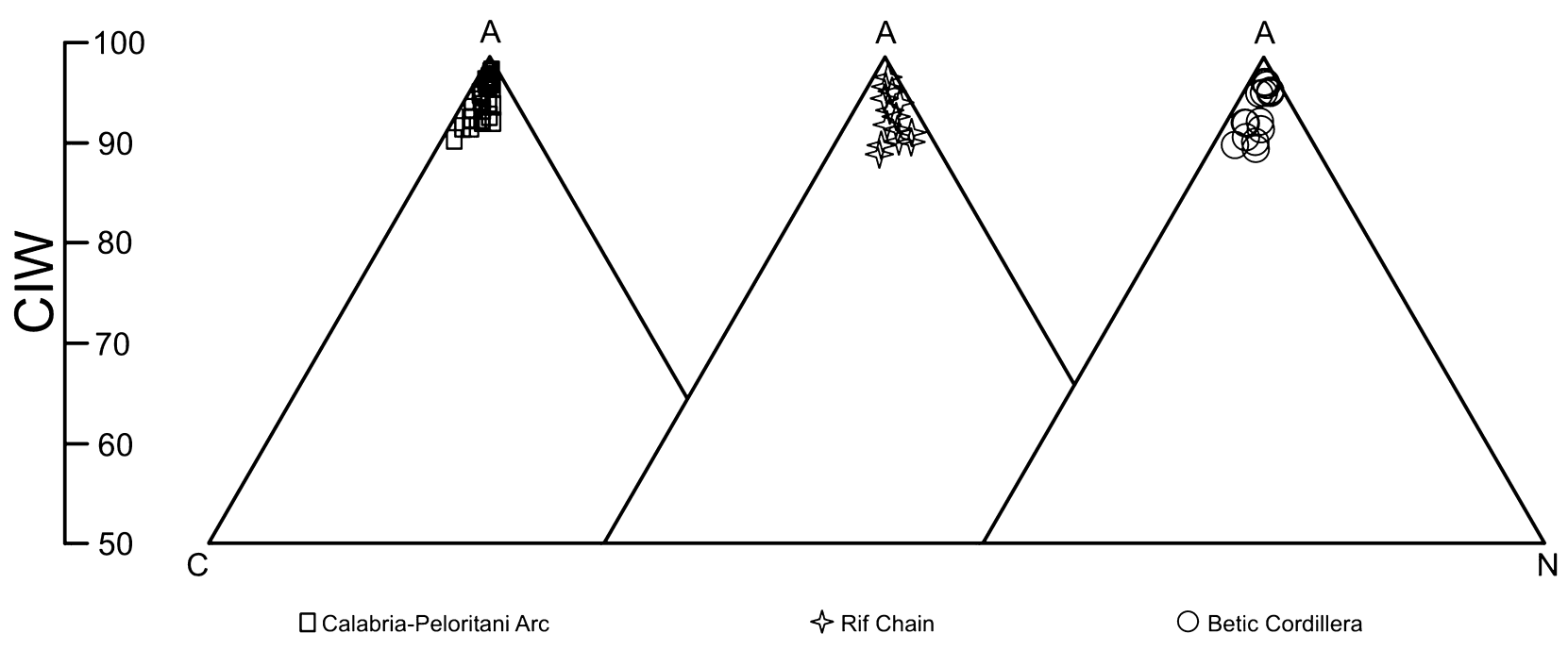

Figure 9. Ternary A-C-N plots of the mudrock redbeds. 

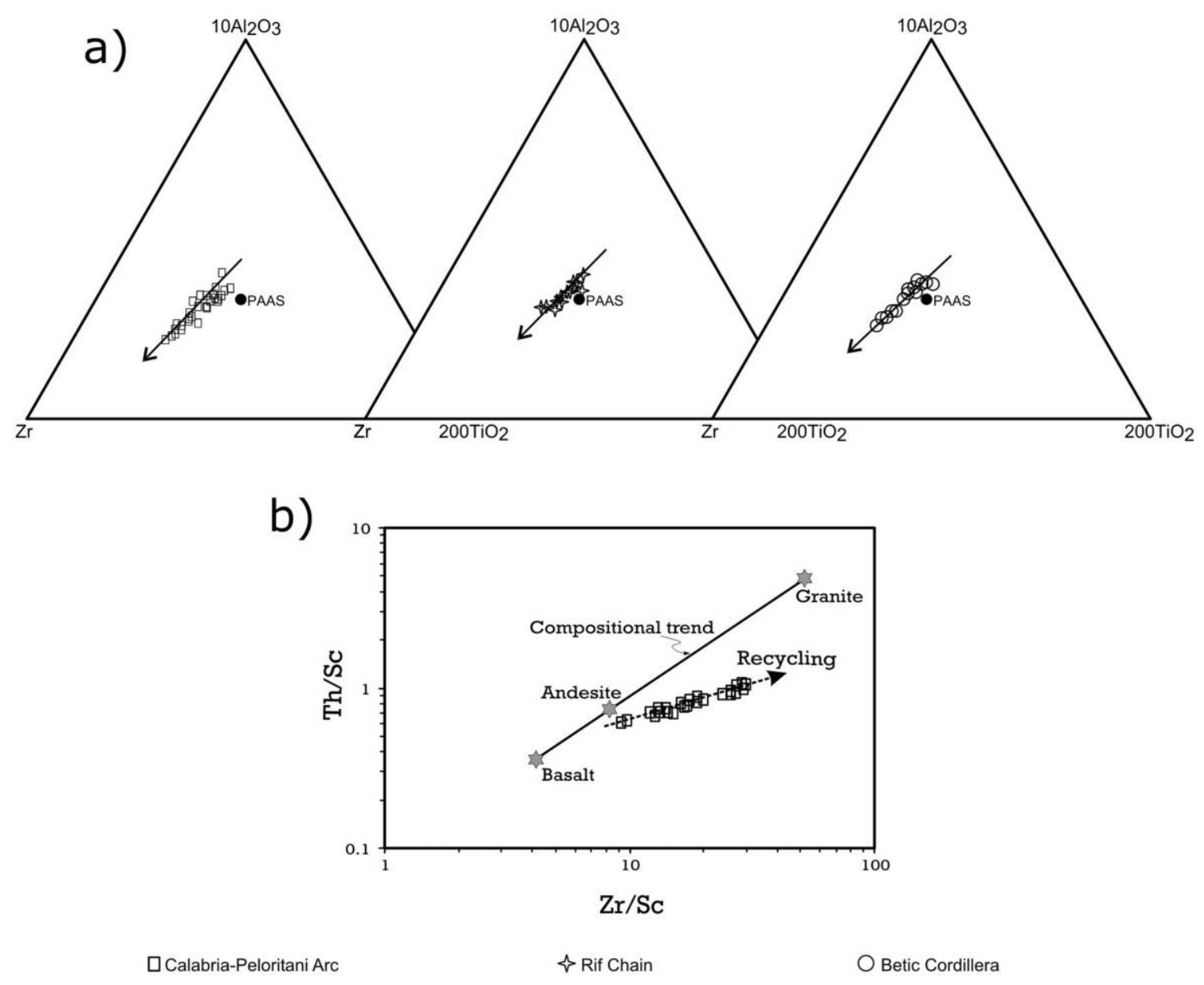

Figure 10. Ternary $10 \mathrm{Al}_{2} \mathrm{O}_{3}-200 \mathrm{TiO} 2$ - $\mathrm{Zr}$ plots showing possible sorting effects ( $a$; see text for more details) and Th/Sc versus $\mathrm{Zr} / \mathrm{Sc}$ plot $(b)$. In $b$, the samples depart from the compositional trend, indicating zircon addition suggestive of a recycling effect.

Hercynian heritage because they were deeply involved in Alpine orogenesis and Uppermost Carboniferous-Permian sedimentary and volcanic terranes are lacking. Upper Paleozoic sedimentary and volcanic terranes, in contrast, are developed in the surrounding regions, such as the Moroccan Atlas, Iberia, Languedoc, Provence, and Sardinia, which were only subordinately involved in Alpine orogenesis (Durand Delga and Fontboté 1980; Baudelot et al. 1984; Martin-Algarra et al. 1995).

The Pseudoverrucano-Verrucano Domains, finally, were the Triassic precursor of a Jurassic-early Miocene continental block, from which the internal units of the Western Mediterranean Alpine Chains originated (Mesomediterranean Microplate; Guerrera et al. 1993, 2005; Bonardi et al. 2001). This microplate, owing to Jurassic-Cretaceous opening of the western Tethys (fig. 2C), separated a northern (Nevadofilabride-Piemontese-Ligurian) branch from an eastern and southern (MaghrebianLucanian) branch of the Tethys (Martín-Algarra 1987; Guerrera et al. 1993, 2005; Perrone 1996; Bonardi et al. 2001; Chalouan et al. 2001; Michard et al. 2002; de Capoa et al. 2003).

\section{A C K N O W L E D G M E N T S}

This work was funded by the Ministero dell'Universtità e della Ricerca Scientifica-Progetto di Ricerca Nazionale (MIUR-PRIN) 2001-2003 Project ("Age and Sedimentary Characters of the Mesozoic Continental Redbeds [Verrucano] from Northern Apennines to the Betic Cordillera: Implications for Paleogeographic and Tectonic Evolution of the Central-Western Mediterranean Alpine Belts," S. Critelli, G. Mongelli, V. Perrone), MIUR-ex60\% Projects ("Paleogeographic and Paleotectonic Evolution of the Circum-Mediterranean Orogenic Belts, 2001-2005" and "Relationships between 
Tectonic Accretion, Volcanism, and Clastic Sedimentation within the Circum-Mediterranean Orogenic Belts, 2006," S. Critelli), the 2006-2008 MIUR-PRIN Project 2006.04.8397 ("The Cenozoic Clastic Sedimentation within the CircumMediterranean Orogenic Belts: Implications for Paleogeographic and Paleotectonic Evolution," S. Critelli, G. Mongelli, V. Perrone), and Research
Project CGL2005-03887 MEC (A. Martin-Algarra). This article benefited from discussions and a revision of an early version of the manuscript by R. V. Ingersoll. We are very grateful to A. Anderson, R. V. Ingersoll, and an anonymous reviewer, who kindly reviewed and improved the final version of the manuscript. This article is dedicated to our dear friend C. Neri.

\section{R E FE R E N C E S C I T E D}

Basu, A. 1985. Influence of climate and relief on compositions of sands released at source areas. In Zuffa, G. G., ed. Provenance of arenites. NATO ASI Ser. Ser. C 148:1-18.

Baudelot, S.; Bouhdadi, S.; and Durand Delga, M. 1984. Datation palynologique du Trias moyen au sein des Grès rouges "Permo-triasiques" des environs de Tétouan (Rif septentrional, Maroc). C. R. Acad. Sci. Ser. II 299:1061-1068.

Bhatia, M. R., and Crook, K. A. W. 1986. Trace element characteristics of graywackes and tectonic setting discrimination of sedimentary basins. Contrib. Mineral. Petrol. 92:181-193.

Bonardi, G.; Cavazza, W.; Perrone, V.; and Rossi, S. 2001. Calabria-Peloritani terrane and northern Ionian Sea. In Vai, G. B., and Martini, I. P., eds. Anatomy of an orogen: the Apennines and adjacent Mediterranean basins. Dordrecht, Kluwer Academic, p. 287-306.

Chalouan, A.; Michard, A.; Feinberg, H.; Montigny, R.; and Saddiqi, O. 2001. The Rif mountain building (Morocco): a new tectonic scenario. Bull. Soc. Geol. Fr. 172:603-616.

Critelli, S. 1999. The interplay of lithospheric flexure and thrust accommodation in forming stratigraphic sequences in the southern Apennines foreland basin system, Italy. Rend. Lincei 10:257-326.

Cullers, R. L. 1994. The controls on the major and trace element variation of shales, siltstones, and sandstones of Pennsylvanian-Permian age from uplifted continental blocks in Colorado to platform sediments in Kansas, USA. Geochim. Cosmochim. Acta 58:49554972.

de Capoa, P.; Di Staso, A.; Guerrera, F.; Perrone, V.; and Tramontana, M. 2003. The extension of the Maghrebian Flysch Basin in the Apenninic Chain: paleogeographic and paleotectonic implications. Trav. Inst. Sci. Rabat Ser. Geol. Geogr. Phys. 21:77-92.

Dickinson, W. R. 1985. Provenance relations from detrital modes of sandstones. In Zuffa, G. G., ed. Provenance of arenites. NATO ASI Ser. Ser. C 148:333-361.

Durand Delga, M., and Fontboté, J. M. 1980. Le cadre structural de la Méditerranée occidentale. Mem. Bur. Rech. Geol. Min. 115:67-85.

Fedo, C. M.; Nesbitt, H. W.; and Young, G. M. 1995. Unraveling the effect of potassium metasomatism in sedimentary rocks and paleosols, with implications for paleoweathering conditions and provenance. Geology 23:921-924.

Frey, M., and Robinson, D. 1999. Low-grade metamorphism. Oxford, Blackwell Science, 328 p.

Garcia, D.; Coehlo, J.; and Perrin, M. 1991. Fractionation between $\mathrm{TiO}_{2}$ and $\mathrm{Zr}$ as a measure of sorting within shale and sandstone series (northern Portugal). Eur. J. Mineral. 3:401-414.

Guerrera, F.; Martín-Algarra, A.; and Perrone, V. 1993. Late Oligocene-Miocene syn-, late-orogenic successions in Western and Central Mediterranean chains from the Betic Cordillera to the Southern Apennines. Terra Nova 5:525-544.

Guerrera, F.; Martín Martín, M.; Perrone, V.; and Tramontana, M. 2005. Tectono-sedimentary evolution of the southern branch of the western Tethys (Maghrebian Flysch Basin and Lucanian Ocean) on the basis of the stratigraphic record. Terra Nova 17:358-367.

Harnois, L. 1988. The C.I.W. index: a new chemical index of weathering. Sediment. Geol. 55:319-322.

Ingersoll, R. V.; Bullard, T. F.; Ford, R. L.; Grimm, J. P.; Pickle, J. D.; andSares, S. W. 1984. The effect of grain size on detrital modes: a test of the Gazzi-Dickinson point-counting method. J. Sediment. Petrol. 54:103116.

Ingersoll, R. V., and Suczek, C. A. 1979. Petrology and provenance of Neogene sand from Nicobar and Bengal fans, DSDP sites 211 and 218. J. Sediment. Petrol. 49: 1217-1228.

Jaboyedoff, M., and Thélin, P. 1996. New data on lowgrade metamorphism in the Briançonnais domain of the pre-Alps, western Switzerland. Eur. J. Miner. 8: 577-592.

Jadgozinski, H. 1949. Eindimensionale Fehlordnung in Kristallen und ihr Einfluss auf die Röntgeninterferenzen. I. Berechnung des ehlordnungsgrades aus den Röntgenintensitaten. Acta Crystallogr. 2:201-207.

Lipman, P. W. 1964. Chemical comparison of glassy and crystalline volcanic rocks. U.S. Geol. Surv. Bull. 1201D, $24 \mathrm{p}$.

Martín-Algarra, A. 1987. Evolucion geologica alpina del contacto entre las Zonas Internas y las Zonas Externas de la Cordillera Betica. PhD thesis, University of Granada, $1171 \mathrm{p}$.

Martín-Algarra, A.; Solé de Porta, N.; and Maate, A. 1995. El Triásico del Maláguide-Gomáride (Formación Salad- 
illa, Cordillera Bética Occidental y Rif Septentrional): nuevos datos sobre su edad y significado palaeogeográfico. Cuad. Geol. Iberica 19:249-278.

Michard, A.; Chalouan, A.; Feinberg, H.; Goffé, B.; and Montigny, R. 2002. How does the Alpine belt end between Spain and Morocco? Bull. Soc. Geol. Fr. 173:3-15.

Mongelli, F.; Harabaglia, P.; Martinelli, G.; Squarcia, P.; and Zito, G. 1996. Nuove misure di flusso geotermico in Italia meridionale: possibili implicazioni sismotettoniche. In Atti del XIV Convegno Annuale del GNGTS (Rome, Oct 23-25, 1995), Proc. XIV GNGTS, p. 929-939.

Mongelli, G. 2004. Rare-earth elements in OligoMiocenic pelitic sediments from Lagonegro basin, southern Apennines, Italy: implications for provenance and source-area weathering. Int. J. Earth Sci. 93:612-620.

Mongelli, G.; Critelli, S.; Perri, F.; Sonnino, M.; and Perrone, V. 2006. Sedimentary recycling, provenance and paleoweathering from chemistry and mineralogy of Mesozoic continental redbed mudrocks, Peloritani Mountains, southern Italy. Geochem. J. 40:197-209.

Nesbitt, H. W., and Young, G. M. 1982. Early Proterozoic climates and plate motions inferred from major element chemistry of lutites. Nature 299:715-717.

- 1989. Formation and diagenesis of weathering profiles. J. Geol. 97:129-147.

Perri, F. 2008. Clay mineral assemblage of the Middle Triassic-Lower Jurassic mudrocks from WesternCentral Mediterranean Alpine chains. Period. Mineral. 77:23-40.

Perrone, V. 1996. Une nouvelle hypothèse sur la position paléogéographique et l'évolution tectonique des Unités de Verbicaro et de San Donato (région calabrolucanienne; Italie): implications sur la limite AlpesApennin en Calabre. C. R. Acad. Sci. Ser. II A 322: 877-884.

Perrone, V.; Martín-Algarra, A.; Critelli, S.; Decandia, F. A.; D'Errico, M.; Estevez, A.; Iannace, A.; et al.
2006. "Verrucano" and "Pseudoverrucano" in the Central-Western Mediterranean Alpine chains: palaeogeographic evolution and geodynamic significance. In Chalouan, A., and Moratti, G., eds. Geology and active tectonics of the westernMediterraneanregionandNorth Africa. Geol. Soc. Lond. Spec. Publ. 262:1-46.

Ratté, J. C., and Steven, T. A. 1967. Ash flows and related volcanic rocks associated with the Creede caldera, San Juan Mountains, Colorado. U.S. Geol. Surv. Prof. Pap. 524-H, 58 p.

Spalletta, C., and Vai, G. B. 1989. Stratigraphic correlation forms of the Calabrian-Peloritan Arc (southern Italy). Rend. Soc. Geol. Ital. 12:411-416.

Suttner, L. J.; Basu, A.; and Mack, G. H. 1981. Climate and the origin of quartz arenites. J. Sediment. Petrol. 51: 1235-1246.

Sweetkind, D. S.; Reynolds, R. L.; Sawyer, D. A.; and Rosenbaum, J. G. 1993. Effects of hydrothermal alteration on the magnetization of the Oligocene Carpenter Ridge Tuff, Bachelor caldera, San Juan Mountains, Colorado. J. Geophys. Res. 98:6255-6266.

Taylor, S. R., and McLennan, S. M. 1985. The continental crust: its composition and evolution. Oxford, Blackwell Scientific, 312 p.

Trombetta, A.; Cirrincione, R.; Corfu, F.; Mazzoleni, P.; and Pezzino, A. 2004. Mid-Ordovician U-Pb ages of porphyroids in the Peloritan Mountains (NE Sicily): palaeogeographical implications for the evolution of the Alboran microplate. J. Geol. Soc. Lond. 161:265276.

Vera, J. A., ed. 2004. Geologia de España. Madrid, SGEIGME, $884 \mathrm{p}$.

Warr, L. N., and Rice, A. H. N. 1994. Interlaboratory standardization and calibration of clay mineral crystallinity and crystal size data. J. Metamorph. Geol. 12: 141-152.

Zuffa, G. G. 1985. Optical analyses of arenites: influence of methodology on compositional results, In Zuffa, G. G., ed. Provenance of arenites. NATO ASI Ser. Ser. C 148:165-189. 